www.jmscr.igmpublication.org

Impact Factor 5.84

Index Copernicus Value: 71.58

ISSN (e)-2347-176x ISSN (p) 2455-0450

crossref DOI: _https://dx.doi.org/10.18535/jmscr/v5i11.67

Journal Of Medical Science And Clinical Research

\title{
A Study of Magnesium Levels in Neonatal Convulsions
}

\author{
Authors \\ Shruti Dhale ${ }^{1}$, Subash Valinjkar ${ }^{2}$, Nilesh Sadhwani ${ }^{3}$, Megha Jhunjhunwala ${ }^{* 4}$ \\ ${ }^{1,2}$ M.D. Paediatrics, Associate Professor, Department of Paediatrics, Grant Govt Medical College, Mumbai \\ ${ }^{3}$ M.D. Paediatrics, Department of Paediatrics, Grant Govt Medical College, Mumbai \\ ${ }^{4}$ D.C.H., Department of Paediatrics, Grant Govt Medical College, Mumbai \\ *Corresponding Author \\ Megha Jhunjhunwala
}

D.C.H., Department of Paediatrics, Grant Govt Medical College, Mumbai

Postal Address: A/802, Mahadev Tower, Thakur Complex, Kandivali East, Mumbai 400101.

Email: meghajhunjhunwala07@gmail.com,Ph no: 8424021337

\begin{abstract}
The association of hypomagnesemia with hypocalcemia is known for the past few years and in majority of these instances, disturbances of magnesium $(\mathrm{Mg})$ homeostasis is secondary to an obvious cause. Primary hypomagnesemia due to disorder of magnesium metabolism though rare, has been reported. In these infants who are both hypomagnesemic and hypocalcemic, symptoms and biochemical disturbances respond only to administration of magnesium salts. Hypomagnesemia is now reported in neonates and during early infancy (3-5) as a result of specific malabsorption of magnesium. ${ }^{[1]}$ Association of hypomagnesemia with calcium deficiency is a known disorder in neonates which needs immediate attention. While most cases occur along with calcium deficiency, there are a sizeable number of cases which have primary magnesium deficiency. Symptomatic hypocalcemia unresponsive to adequate doses of IV calcium therapy is usually due to hypomagnesemia. It may present either as Early Neonatal Hypocalcemia or later as Late Neonatal Hypocalcemia. ${ }^{[2]}$ The objectives of our study were to find out the incidence of hypomagnesemia in neonatal seizures and to study its correlation with hypomagnesemia.

Methods: A arbitrary sample size of 70 was decided for this particular study based on average number of yearly admissions of neonatal seizures.For the purpose of our study, Serum Magnesium Levels below $1.6 \mathrm{mg} / \mathrm{dl}$ was considered as Hypomagnesemia and a Serum Ionic Calcium Level of less than $3.9 \mathrm{mg} / \mathrm{dl}$ was considered as Hypocalcemia. ${ }^{[3]}$ Clinical examination of all study subjects was conducted. All relevant investigations such as hemoglobin, complete blood count, random blood sugar, ultra sonogram of Skull, electroencephalogram, Serum Magnesium, Serum Calcium and cerebrospinal fluid examination was done and duly noted.The descriptive statistics was analysed as ratios \& percentages. The quantitative data was expressed as measn $\pm S D$ and chi-square test applied if applicable.
\end{abstract}

Results: Hypoxic-ischemic encephalopathy (HIE)\& Meningitis were the 2 major causes of neonatal seizures in our population, which amounted to approximately $73 \%$ of cases of neonatal seizures. The important causes of electrolyte imbalances leading to neonatal seizures were Hypocalcemia (12.86\%) and Hypomagnesemia (2.86\%). Out of the 2 cases of Hypomagnesemia, 1 case was associated with Hypocalcemia (i.e. mixed electrolyte imbalance).

Conclusion: $50 \%$ of the neonates had no specific risk factors associated with hypocalcemia \& hypomagnesemia. The important causes of electrolyte imbalances leading to neonatal seizures were Hypocalcemia (12.86\%) and Hypomagnesemia (2.86\%).Out of the 2 cases of Hypomagnesemia, 1 case was associated with Hypocalcemia (i.e. mixed electrolyte imbalance). The mean $( \pm S D$ ) levels of serum ionic calcium in our study population was $4.64 \pm 0.94$ $\mathrm{mg} / \mathrm{dl}$ while that of serum magnesium was $1.78 \pm 0.13 \mathrm{mg} / \mathrm{dl}$. There was no evidence of a Linear Correlation between the 2 variables $(p>0.05)$.

Keywords: hypomagnesemia, hypocalcemia, neonatal seizures. 


\section{Introduction}

Magnesium is the second most abundant intracellular cation and plays an essential role in neuronal, skeletal and cardiac tissue. Hypomagnesaemia can cause hypocalcaemia by inhibiting parathyroid hormone release and inducing resistance at its receptor sites. Untreated hypomagnesaemia can lead to tetany, recurrent seizures, status epilepticus and life-threatening arrhythmias. ${ }^{[4]}$ Primary hypomagnesaemia with secondary hypocalcaemia (HSH) is a rare metabolic disorder of intestinal magnesium absorption. The condition typically presents in the neonatal period with neuromuscular excitability and seizures refractory to antiepileptic therapy. Early diagnosis and prompt magnesium replacement are essential to prevent death or longterm neuro developmental sequelae. Fewer than a hundred cases are reported in the literature. Recent advances have added significantly to our understanding of the genetic basis of HSH. ${ }^{[4]}$ There is no physiologic hormonal control of plasma magnesium and urinary magnesium excretion. Changes in intake are balanced by changes in urinary magnesium reabsorption, principally in the loop of Henle and the distal tubule in response to changes in plasma magnesium concentration. There are therefore two major mechanisms by which hypomagnesemia can be induced: gastrointestinal or renal losses. Regardless of the cause, hypomagnesemia begins to occur after a relatively small magnesium deficit, because there is little rapid exchange of extracellular magnesium with the much larger bone and cell stores. The objectives of our study were to find out the incidence of hypomagnesemia in neonatal seizures and to study its correlation with hypomagnesemia.

\section{Materials and Method}

This was a prospective study carried out in a tertiary care hospital in a metropolitan city. By universal sampling an arbitrary sample size of 70 was decided for this particular study based on average number of yearly admissions of neonatal seizures. All neonates admitted with seizures were included in the study except for neonates who were on drugs causing hypocalcemia. the study was conducted from January 2015 to December 2016. Serum total calcium (Arsenazo, Erba full auto EM 360) and magnesium (Xylidyl blue, Erba full auto EM 360). were measured. For the purpose of our study, Serum Magnesium Levels below $1.6 \mathrm{mg} / \mathrm{dl}$ was considered as Hypomagnesemia and a Serum Ionic Calcium Level of less than $3.9 \mathrm{mg} / \mathrm{dl}$ was considered as Hypocalcemia. ${ }^{[3]}$ Approval for conduction of study was taken from Institutional Ethics Committee. Demographic details of all study subjects was noted. Detailed history was taken from the informant of the study subjects regarding the symptoms, family history etc. Clinical examination of all study subjects was conducted. All relevant investigations such as $\mathrm{Hb}, \mathrm{CBC}$, RBS, USG Skull, EEG, Serum Magnesium, Serum Calcium and CSF examination was done and duly noted.Data entry was done by the investigator using Microsoft Excel 2008 version. Statistical Analysis was done using Graph Pad Instat Version 4.0.The descriptive statistics was analysed as ratios \& percentages. The quantitative data was expressed as measn $\pm \mathrm{SD}$ and chi-square test applied if applicable.

\section{Results}

Table 1: Causes of Neonatal Seizures

\begin{tabular}{|c|c|c|}
\hline Neonatal History: & $\mathbf{n = 7 0}$ & Perce ntage \\
\hline $\begin{array}{c}\text { Hypoxic Is - chaemic En - } \\
\text { cephalopat hy (HIE) }\end{array}$ & 32 & $45.71 \%$ \\
\hline Meningitis & 19 & $27.14 \%$ \\
\hline Hypocalce mia & 9 & $12.86 \%$ \\
\hline Hypomagn e s e mia & 2 & $2.86 \%$ \\
\hline Hypoglycemia & 4 & $5.71 \%$ \\
\hline $\begin{array}{c}\text { Intra- Ventricular } \\
\text { Haemorrh age (IVH) } \\
\text { (Hy - droceph alu s As- } \\
\text { sociated with MMC) }\end{array}$ & 4 & $5.71 \%$ \\
\hline
\end{tabular}

- HIE \& Meningitis were the 2 major causes of neonatal seizures in our population, 
which amounted to approximately $73 \%$ of cases of neonatal seizures.

- The important causes of electrolyte imbalances leading to neonatal seizures were Hypocalcemia (12.86\%) and Hypomagnesemia (2.86\%).

- Out of the 2 cases of Hypomagnesemia, 1 case was associated with Hypocalcemia (i.e. mixed electrolyte imbalance).

Table 2: Causality Assessment of Hypocalcemia

\begin{tabular}{|l|c|c|}
\hline Risk Factors & $\mathbf{n = 9}$ & Percentage \\
\hline $\begin{array}{l}\text { Premature } \\
\text { Delivery }\end{array}$ & 3 & $4.29 \%$ \\
\hline $\begin{array}{l}\text { Gestational Dia } \\
\text { betes Mellitus }\end{array}$ & 4 & $5.71 \%$ \\
\hline Photothera py & 2 & $2.85 \%$ \\
\hline Total & $\mathbf{9}$ & $\mathbf{1 2 . 6 8 \%}$ \\
\hline
\end{tabular}

- Gestational diabetes mellitus and Premature delivery were associated in 4 $(5.71 \%)$ and 3 cases $(4.29 \%)$ respectively in hypocalcemic neonates, while a history of phototherapy immediately after birth was associated in 2 of these cases $(2.85 \%)$.

Table 3: Causality Assessment of Hypomagnesemia

\begin{tabular}{|l|c|c|}
\hline Risk Factors: & $\mathrm{n}=70$ & Perce $\mathrm{n}$ tage \\
\hline $\begin{array}{l}\text { Unknown (C/O Hypomag n e - } \\
\text { semia) }\end{array}$ & 1 & $1.43 \%$ \\
\hline $\begin{array}{l}\text { Gestational Dia - betes Mellitus } \\
\text { (C/O Hypomagn e - semia with } \\
\text { Hypocalce mia) }\end{array}$ & 1 & $1.43 \%$ \\
\hline Total & 2 & $2.86 \%$ \\
\hline
\end{tabular}

- On detailed history and examination, no risk factor was found to be associated with the only case of hypomagnesemic seizure.

- While in case of hypomagnesemia with additional hypocalcemic seizure, the mother had a history of gestational diabetes mellitus.

- However, these associational findings can be only confirmed when the study is done in a larger population of such patients with specific causality assessment.
Table 4: Serum Levels of Calcium \& Magnesium Ions:

\begin{tabular}{|c|c|c|}
\hline Electrolyt e: & Mean $( \pm$ S D $)$ : & $\begin{array}{l}\text { Median } \\
\text { [Range] }\end{array}$ \\
\hline $\begin{array}{l}\text { Serum Total } \\
\text { Calcium }\end{array}$ & $\begin{array}{c}6.92 \pm 0.63 \\
\mathrm{mg} / \mathrm{dl}\end{array}$ & $\begin{array}{c}7.1[5.2,8.2] \\
\mathrm{mg} / \mathrm{dl}\end{array}$ \\
\hline $\begin{array}{l}\text { Serum Ionic } \\
\text { Calcium }\end{array}$ & $\begin{array}{c}4.64 \pm 0.94 \\
\mathrm{mg} / \mathrm{dl}\end{array}$ & $\begin{array}{c}4.9[2.5,6.3] \\
\mathrm{mg} / \mathrm{dl}\end{array}$ \\
\hline $\begin{array}{l}\text { Serum } \\
\text { Magnesium }\end{array}$ & $\begin{array}{c}1.78 \pm 0.13 \\
\mathrm{mg} / \mathrm{dl}\end{array}$ & $\begin{array}{c}1.87[1.46,1.92] \\
\mathrm{mg} / \mathrm{dl}\end{array}$ \\
\hline
\end{tabular}

Further, on applying Correlation Analysis (Spearman r) for Serum Ionic Calcium levels (YAxis) and Serum Magnesium levels (X-Axis), we found that:

Spearman $r=-0.01047$ (corrected for ties) (No Gaussian Assumptions)

95\% confidence interval was: -0.1809 to 0.1606

The two-tailed $\mathrm{P}$ value was 0.9023 , considered not significant.

Hence, there was no evidence of a Linear Correlation between the 2 variables.

\section{Discussion}

The objectives of our study were to find out the incidence of hypomagnesemia in neonatal seizures and to study its correlation with hypomagnesemia in 70 cases of neonatal seizures.

The overall incidence of seizures caused due to electrolyte imbalance in our study was 11 $(15.72 \%)$ out of the 70 cases of neonatal seizures evaluated. 9 cases out of these were associated with hypocalcemia while 2 cases were associated with hypomagnesemia. Only one of the cases of hypomagnesemia was associated with hypocalcemia. The mean $( \pm \mathrm{SD})$ levels of serum ionic calcium in our study population was $4.64 \pm 0.94$ $\mathrm{mg} / \mathrm{dl}$ while that of serum magnesium was $1.78 \pm$ $0.13 \mathrm{mg} / \mathrm{dl}$. There was no evidence of a Linear Correlation between the 2 variables $(p>0.05)$. The results of a study conducted by Taksande AM et al (2005) who studied 110 neonates with neonatal seizures found that hypocalcemia and hypoglycemia were the most common biochemical abnormality seen in neonates with seizures ${ }^{[5]}$ and is in concordance with our findings both in duration of the study as well as the study 
findings related to hypomagnesemia and hypocalcemia. Talebian A et al (2015) conducted a study for detection of seizure, its etiology, and clinical types in 100 neonates hospitalized foe neonatal seizures. The etiologies of seizures were hypoxicischemic encephalopathy (HIE) (36\%), hyponatremia (12\%), hypoglycemia (11\%), intracranial hemorrhage $(11 \%)$, infections (10\%), hypocalcemia (8\%), metabolic disorders (7\%), the structural anomalies (5\%), and hypomagnesaemia $(4 \%)$ which is similar to our study.

\section{Conclusion}

The important causes of electrolyte imbalances leading to neonatal seizures were Hypocalcemia $(12.86 \%)$ and Hypomagnesemia (2.86\%). Out of the 2 cases of Hypomagnesemia, 1 case was associated with Hypocalcemia (i.e. mixed electrolyte imbalance).The mean $( \pm \mathrm{SD})$ levels of serum ionic calcium in our study population was $4.64 \pm 0.94 \mathrm{mg} / \mathrm{dl}$ while that of serum magnesium was $1.78 \pm 0.13 \mathrm{mg} / \mathrm{dl}$. There was no evidence of a Linear Correlation between the 2 variables ( $p>$ 0.05 ). The important limitaions in our study is the short duration of the study. A cross-sectional prevalance study of 5 years (both retrospective \& prospective) would have given us a beter picture of the various risk factors and causes of neonatal seizures in our population. But this was not possible in our setting due to inadequate record keeping. A increased sample size would have given us a better understanding of the causes and progression of electrolyte imbalances in the neonatal population, thereby providing a better idea of the prognosis of neonatal seizures related to hypomagnesemia and hypocalcemia.

\section{References}

1. Skyberg D, Stromme JH, Nesbakken R, Harnoe K. Neonatal hypomagnesemia with selective malabsorption of magnesium. Scand J Clin Lab Invest 1968; 21: 355361.
2. Heaton FW, Fourman P. Magnesium deficiency and hypocalcaemia in intestinal malabsorption. Lancet 1965; 2:50.

3. Engron BA, Flerlage JC. Blood Chemistry and Body Fluids: Reference Values. In: Engron BA, Flerlage JC. (Eds.). The Harriet Lane Handbook: A Manual for Pediatric House Officers Philadelphia, PA : Mosby Elsevier; 2014. p. 621-33.

4. Ryzen E: Magnesium homeostasis in critically ill patients. Magnesium 1989;8: 201-212.

5. Taksande . A, Vilhekar K, Jain M, Lakra M. Clinico-biochemical profile of neonatal seizures. Pediatric Oncall 2005;2:166-75. 